\title{
The COVID-19 Pandemic Endangers Africa's Indigenous Pygmy Populations
}

\author{
Julia E. Fa, ${ }^{1,2}$ Robert Nasi, ${ }^{2}$ and Stephan M. Funk ${ }^{3}$ \\ ${ }^{1}$ Department of Natural Sciences, School of Science and the Environment, Manchester Metropolitan University, Manchester M1 5GD, UK \\ ${ }^{2}$ Center for International Forestry Research (CIFOR), CIFOR Headquarters, Bogor 16115, Indonesia \\ ${ }^{3}$ NatureHeritage, Jersey, Channel Islands, UK
}

Keywords: COVID-19, Pygmy People, Baka, Indigenous health, Poverty, Cameroon

Forest-dependent populations are affected by environmental pressures that include deforestation and forest degradation. Their lives and livelihoods have also been transformed by political decisions in the countries where they live. In Africa, the Pygmy peoples living in the dense tropical forests $\left(4\right.$ million $\mathrm{km}^{2}$ ) that span west-east along the central African belt of the Congo Basin are made up of genetically and ethnolinguistically distinct groups (Bahuchet 2014). They are broadly subdivided into western groups, including Baka and Aka, and eastern groups including Mbuti, Efe, and Asua. All have a similar way of life associated with forest hunting and gathering even though some have taken up some form of agriculture. Additionally to their mode of subsistence, they share distinctive cultural and phenotypic traits such as the "Pygmy phenotype" of small adult body size (Perry and Dominy 2009). The demographic and evolutionary split between Pygmy and non-Pygmy populations is amongst the oldest for modern humans with the divergence estimated from genetic data to be roughly between 60,000 and over 100,000 years ago and the split between Western and Eastern Pygmy groups about 20,000 years ago (Hsieh et al. 2016). The Baka in south-eastern Cameroon, formerly strict hunters-gatherers, still practice a subsistence economy, but also maintain a close association with sedentary Bantu-

Published online: May 27, 2021

Correspondence to: Stephan M. Funk, e-mail: smf@natureheritage.org speaking swidden agriculturalists with whom they have a complex social, economic, and symbolic relationship (Joiris 1998). Although less isolated than other Pygmy groups, especially the Mbuti and Efe, the Baka, like other forestdependent populations in the Congo Basin, have been affected by a plethora of environmental pressures that include direct impacts from extractive industries (logging, mining), conflict with conservation areas, encroachment into their territories both peacefully along roads or aggressively by poachers and militias, as well as the effects of resettlement and sedentarization (Olivero et al. 2016). Such combination of threats impacts their health and food security. Currently, COVID-19 has reached Africa though apparently with an overall surprisingly low prevalence and mortality (Mbow et al. 2020). We argue that Pygmy communities may be silently ravaged by the disease yet there is a lack of policies or initiatives to monitor their health systematically throughout the Congo Basin. Understanding the impact of COVID-19 on these forest-dependent peoples has never been more important to develop ways of helping them.

The first fatalities of the 2020 COVID-19 pandemic amongst Amazonian tribes have highlighted the potential catastrophe that the novel coronavirus can bring to isolated Indigenous Peoples (Phillips 2020). Pygmy health is precarious, as exemplified by the Aka in Central African Republic and the Twa in Uganda that have infant mortality rates 1.5-4 times higher than the neighbouring non-Pygmy 
populations (Jackson 2006). Baka Pygmies in Cameroon die on average 22 years earlier than their non-Pygmy neighbours (Anderson et al. 2016; The Lancet 2016). It is the example par excellence highlighting the health inequality in which Indigenous People find themselves (The Lancet 2016). A recent paper by Carson et al. (2018), published in this journal, demonstrated that the Baka in Cameroon have poorer health outcomes than the general population due to the lack of traditional medicine usage, health access, and indigenous health equity. Moreover, some Baka also are suspicious to Western medicine.

Data available from five representative Demographic and Health Surveys in sub-Saharan countries with Pygmy populations also show that Pygmies are the poorest (Funk et al. 2020). Linked to this, studies of Body Mass Index (BMI), an indicator of nutritional status, demonstrate that Pygmies are at the lowest end compared to their nonPygmy neighbours. Besides, there is a declining or stagnant trajectory of Pygmy BMI over age that does not occur in the other groups (Funk et al. 2020). This means that the typically low BMI in Pygmies is linked to primary immunodeficiency which in turn can explain an elevated mortality and morbidity, even in mild forms of undernutrition (Bourke et al. 2016). The observed decline in adult BMI with age in Pygmies may make the older cohorts inordinately susceptible to the COVID-19 pandemic. On the other hand, there is a greater magnitude of immune activation and response in rural African peoples compared to urban Africans and Europeans, highlighting the impact of lifestyle and exposure to pathogens on the immune system (Mbow et al. 2014). Moreover, the "hygiene hypothesis" (Yazdanbakhsh 2002) suggest that persistent immune challenges in adverse environments might trigger more adequate immune response to new infections such as SARS-CoV-2 (Mbow et al. 2020). Whether the hygiene hypothesis holds for Pygmy people considering their dramatically reduced life expectancy compared to their nonPygmy neighbours appears doubtful, but cannot be excluded for SARS-CoV-2. However, there are no data about immune responses of Pygmy people to coronaviruses or other infectious diseases.

Pygmies are possibly not only affected directly by the pandemic itself but, because of their dispersion, and low densities in forests, are unlikely to be protected by social distancing and vaccination strategies. Intervention in isolated Pygmy populations is not advisable because of the risk of disease introduction. A worldwide ban on wild meat hunting and trade as has been suggested because of the link between COVID-19 and wet markets (Born Free Foundation 2020), but will affect the food security and livelihoods of millions of the poorest people. For Indigenous Peoples and myriad rural communities, consumed and also sold wild meat remains the backbone of their ways of life ( $\mathrm{Fa}$ et al. 2015) despite that numerous groups are no longer fully nomadic but have been dragged into our economic system. Hence, stopping short food supply chains can be a blunt tool which will imperil vulnerable peoples even more. This is not to say that urban wild meat consumption and any illegal and unregulated wildlife trade that endangers human health, animal welfare, and biodiversity should not be banned, but extra care is required so that we can protect the already precarious food security of vulnerable Indigenous People such as the Pygmies who rely on hunting and consumption of wild meat. In the case of the Twa Pygmies in Uganda, exclusion from their traditional land in the 1990s caused severe poverty and hardship and high mortality rates amongst under-five year olds. Only after Twa families were given land and hunting rights, mortality rates dropped from 59 to $18 \%$, demonstrating the crucial importance of land for survival (Jackson 2006).

Pygmy populations in Central Africa right now face a potential "double whammy" of the devastating impacts of the COVID-19 pandemic as well as the potential restriction of hunting and food provisioning to combat future zoonotic risks that will damage their food security and livelihoods. Any rational solution to these issues must consider the potential dangers of the COVID-19 pandemic as an opportunity to take stock of the unprecedented pressures on African Pygmy populations and other Indigenous groups, and provide measured and adequate support for these most vulnerable people on Earth. Actions to reduce zoonotic risk by regulating wildlife hunting and consumption need to step away from draconian measures and steer closer to balancing human needs with animal welfare, food security, disease risk, and traditional rights.

We declare no competing interests. We acknowledge the very helpful comments and suggestions by an anonymous reviewer.

\section{REFERENCES}

Anderson I, Robson B, Connolly M, Al-Yaman F, Bjertness E, King A, Tynan M, Madden R, Bang A, Coimbra CEA, Pesantes MA, Amigo H, Andronov S, Armien B, Obando DA, Axelsson P, Bhatti ZS, Bhutta ZA, Bjerregaard P, Bjertness MB, BricenoLeon R, Broderstad AR, Bustos P, Chongsuvivatwong V, Chu J, 
Deji Gouda J, Harikumar R, Htay TT, Htet AS, Izugbara C, Kamaka M, King M, Kodavanti MR, Lara M, Laxmaiah A, Lema C, Taborda AML, Liabsuetrakul T, Lobanov A, Melhus M, Meshram I, Miranda JJ, Mu TT, Nagalla B, Nimmathota A, Popov AI, Poveda AMP, Ram F, Reich H, Santos RV, Sein AA, Shekhar C, Sherpa LY, Skold P, Tano S, Tanywe A, Ugwu C, Ugwu F, Vapattanawong P, Wan X, Welch JR, Yang G, Yang Z, Yap L (2016) Indigenous and tribal peoples' health (The LancetLowitja Institute Global Collaboration): a population study. The Lancet 388:131-157. https://doi.org/10.1016/S01406736(16)00345-7

Bahuchet S (2014) Cultural diversity of African Pygmies. In: Hunter-gatherers of the Congo Basin: cultures, histories and biology of African Pygmies, Hewlett BS (editor), New Brunswick, NJ: Transaction Publishers, pp 1-29

Born Free Foundation (2020) Live Wild Animal Markets, Human and Animal Health, and Biodiversity Protection. Open letter to the World Health Organisation, United Nations Environment Programme and Office International Epizoologie

Bourke CD, Berkley JA, Prendergast AJ (2016) Immune Dysfunction as a Cause and Consequence of Malnutrition. Trends in Immunology 37:386-398. https://doi.org/10.1016/ j.it.2016.04.003

Fa JE, Olivero J, Real R, Farfán MA, Márquez AL, Vargas JM, Ziegler S, Wegmann M, Brown D, Margetts B, Nasi R (2015) Disentangling the relative effects of bushmeat availability on human nutrition in central Africa. Sci Rep 5:8168. https:// doi.org/10.1038/srep08168

Funk SM, Palomo Guerra B, de Mena Martínez N, Ickowitz A, Fa JE (2020) Divergent trajectories of BMI over age for adult Baka Pygmy people and their sympatric non-Pygmy populations. Human Ecology . https://doi.org/10.1007/s10745-020-00151-7

Hsieh P, Veeramah KR, Lachance J, Tishkoff SA, Wall JD, Hammer MF, Gutenkunst RN (2016) Whole-genome sequence analyses of Western Central African Pygmy hunter-gatherers reveal a complex demographic history and identify candidate genes under positive natural selection. Genome Res 26:279-290. https://doi.org/10.1101/gr.192971.115

Jackson D (2006) The Health Situation of Women and Children in Central African Pygmy Peoples. In: Forest Peoples Programme. http://www.forestpeoples.org/es/node/942. Accessed 5 Mar 2020

Joiris DV (1998) La chasse, la chance, le chant: aspect du systeme ritual des Baka du Cameroun. Ph.D. thesis, Université Libre de Bruxelles

Mbow M, de Jong SE, Meurs L, Mboup S, Dieye TN, Polman K, Yazdanbakhsh M (2014) Changes in immunological profile as a function of urbanization and lifestyle. Immunology 143:569-577. https://doi.org/10.1111/imm.12335

Mbow M, Lell B, Jochems SP, Cisse B, Mboup S, Dewals BG, Jaye A, Dieye A, Yazdanbakhsh M (2020) COVID-19 in Africa: Dampening the storm? Science 369:624-626. https://doi.org/ 10.1126/science.abd3902

Olivero J, Fa JE, Farfán MA, Lewis J, Hewlett B, Breuer T, Carpaneto GM, Fernández M, Germi F, Hattori S, Head J, Ichikawa M, Kitanaishi K, Knights J, Matsuura N, Migliano A, Nese B, Noss A, Ekoumou DO, Paulin P, Real R, Riddell M, Stevenson EGJ, Toda M, Vargas JM, Yasuoka H, Nasi R (2016) Distribution and Numbers of Pygmies in Central African Forests. PLOS ONE 11:e0144499. https://doi.org/10.1371/journal.pone.0144499

Perry GH, Dominy NJ (2009) Evolution of the human pygmy phenotype. Trends in Ecology \& Evolution 24:218-225. https:// doi.org/10.1016/j.tree.2008.11.008

Phillips T (2020) 'We are on the eve of a genocide': Brazil urged to save Amazon tribes from Covid-19. The Guardian

The Lancet (2016) Indigenous health: a worldwide focus. The Lancet 388:104. https://doi.org/10.1016/S0140-6736(16)31020-0

Yazdanbakhsh M (2002) Allergy, Parasites, and the Hygiene Hypothesis. Science 296:490-494. https://doi.org/10.1126/science.296.5567.490 